\title{
Social Justice in Malaysian Racial Society through Maqasid Syariah Framework: From the Media Paradigm
}

Siti Nor Azhani Mohd Tohar, Nur Mohammad Hadi Zahalan, Fauziah Hassan

To Link this Article: http://dx.doi.org/10.6007/IJARBSS/v11-i11/11021 DOI:10.6007/IJARBSS/v11-i11/11021

Received: 17 September 2021, Revised: 20 October 2021, Accepted: 30 October 2021

Published Online: 07 November 2021

In-Text Citation: (Tohar et al., 2021)

To Cite this Article: Tohar, S. N. A. M., Zahalan, N. M. H., \& Hassan, F. (2021). Social Justice in Malaysian Racial Society through Maqasid Syariah Framework: From the Media Paradigm. International Journal of Academic Research in Business and Social Sciences, 11(11), 381 - 390.

Copyright: (c) 2021 The Author(s)

Published by Human Resource Management Academic Research Society (www.hrmars.com)

This article is published under the Creative Commons Attribution (CC BY 4.0) license. Anyone may reproduce, distribute, translate and create derivative works of this article (for both commercial and non-commercial purposes), subject to full attribution to the original publication and authors. The full terms of this license may be seen at: http://creativecommons.org/licences/by/4.0/legalcode

Vol. 11, No. 11, 2021, Pg. $381-390$

Full Terms \& Conditions of access and use can be found at http://hrmars.com/index.php/pages/detail/publication-ethics 


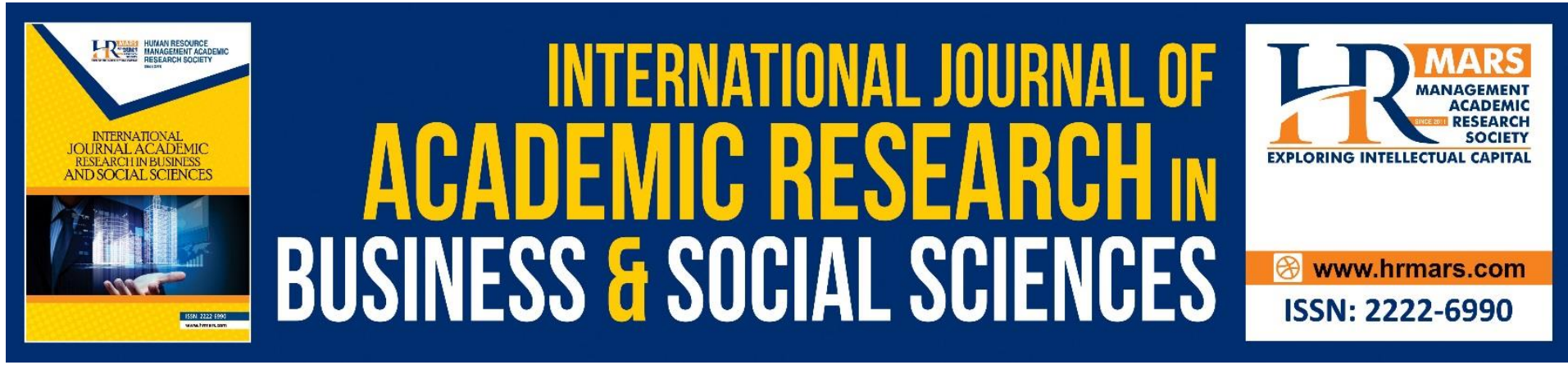

\title{
Social Justice in Malaysian Racial Society through Maqasid Syariah Framework: From the Media Paradigm
}

\author{
Siti Nor Azhani Mohd Tohar \\ Centre for Core Studies, Faculty of Leadership \& Management, Universiti Sains Islam \\ Malaysia, Bandar Baru Nilai, 71800 Negeri Sembilan, Malaysia \\ Email: azhanitohar@usim.edu.my
}

Nur Mohammad Hadi Zahalan

Al-Bayan Global No.18, Jalan Putera 6/1, Seksyen 1, Bandar Mahkota Cheras, 43200 Kajang, Selangor, Malaysia

\section{Fauziah Hassan}

Faculty of Leadership \& Management, Universiti Sains Islam Malaysia, Bandar Baru Nilai, 71800 Negeri Sembilan, Malaysia

\begin{abstract}
The discussion of social justice is inevitable, and has been widely debated and discussed since the advent of the Second World War. The many aspects of social justice often discussed include equity, fairness, injustice, rationality, altruism, et cetera. However, the social justice framework, especially within a multi-ethnic context, requires further elaboration and explanation via the Maqasid Syariah perspective, in order to build a solid foundation of racial unity in line with the principles of the Malaysian Constitution. Therefore, this paper, using content analysis technique of existing literature, forges a direction for social justice within the multi-ethnic context in Malaysia, examined through the lens of Maqasid Syariah. In addition, this paper also looks into the role of the media in promoting Malaysian social justice. As the media is strongly influential in educating and disseminating messages to the mass public, it is important to enhance the role of the media in promoting a more accurate depiction of social justice to the society. Thus, this is an important discussion worth having, not least to ensure social justice in Malaysia is developed within the context of Malaysian society, especially with Islam as the religion of the Federation of Malaysia.
\end{abstract}

Keywords: Social Justice, Multi-ethnic, Racial Unity, Maqasid Syariah, Social Media.

\section{Introduction}

Social justice has been widely debated and discussed since the advent of the Second World War, and assumed prominence in public debates and international legal arenas during the late 20th and early 21st centuries (Capenheart and Milovanovic, 2007). Social justice is often 
linked to issues of poverty, disadvantage, injustice, oppression, stigma, and discrimination. Therefore, in order to address these issues, concepts of freedom, justice, equality, human rights, dignity, democracy, and theories of distribution are often discussed within the frameworks of economy, healthy, education (Watts \& Hodgson, 2019), and language (Avineri, et. al. 2019; Reagan, 2019). In addition, virtually every nation state in the modern world is no longer tied to ethnicity as the key national identity, as the multi-ethnic and multi-cultural composition is experienced everywhere. Social justice, within an ethnic framework, is often a hotly-debated issue in any given country (Avineri et al., 2019). The discussion often centre around both dominant and minority ethnic groups (Henderson, et. al. 2019) and injustice often advocates for the minority instead of the dominant ethnic group (Green, Glaser, \& Rich, 1998). In fact, 600 years ago a sociologist, Ibn Khaldun, discusses the situation of inter-ethnic competition for national dominance and leadership (Ibn Khaldun, 1967) to ensure the welfare of their people. With this in mind, this article uses the literary analysis technique to address the formation of racial unity through the Maqasid Syariah, its application relevant not only to Muslims, but as a basis of multi-ethnic unity in Malaysia. This article also discusses the role of social media in highlighting social justice issues within a more harmonious space, in line with the principles of the Malaysian Constitution, which takes into account the legitimate and equitable needs of all ethnic groups.

\section{The Definition of Maqasid al-Syari'ah}

Maqasid Al-Syari'ah is defined as the understanding of the wisdom behind each ruling prescribed in Syari'ah to either increase benefits or to reduce harm. The Syari'ah, according to Islamic methodology, means anything that has been set by Allah for his servants in the perspective of faith, worship or devotion, moral values, transactions and anything that involves human actions on earth. Nevertheless, according to Imam al-Syatibi (2005), the reasoning behind the creation of syariat or rulings is for the realization of maqasid for all mankind, that is to ensure the benefits (maslahah) and avoid harm (mafsadah) whether here on earth or in the hereafter.

Maqasid Syariah not only focuses on the Syariah elements, but also on faith (aqidah) and moral values (akhlak). The following will describe the categories of benefits (maslahah) in brief:

1. Ad-Dhoruriat (the necessities) in Arabic is الضروريات which includes the most essential elements in life and cannot be left out. To do so would mean deprivation and damage to life. Scholars agree on the five (5) main cores of Ad-Dhoruriat as follows:
a) Protection of religion
b) Protection of self
c) Protection of intellect
d) Protection of progeny
e) Protection of wealth

Allah SWT has outlined the importance of preserving the above maslahah Ad-Dhoruriyat in Surah Al-Mumtahanah verse 12:

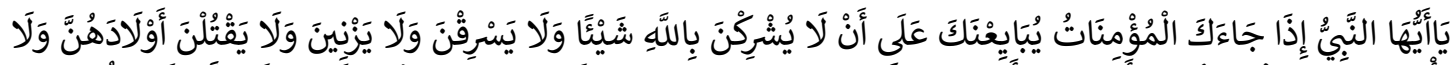

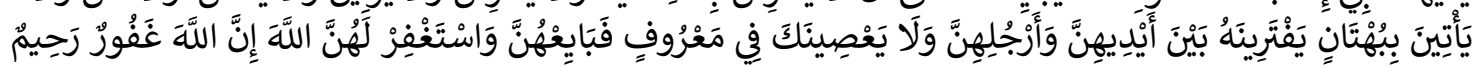


Meaning: O Prophet, when the believing women come to you pledging to you that they will not associate anything with Allah, nor will they steal, nor will they commit unlawful sexual intercourse, nor will they kill their children, nor will they bring forth a slander they have invented between their arms and legs, nor will they disobey you in what is right - then accept their pledge and ask forgiveness for them of Allah. Indeed, Allah is Forgiving and Merciful.

2. Al-Hajiyyat (the needs) in Arabic is termed as الحاجيات is whatever that is needed by humanity to alleviate hardship and difficulties.This is different from Al-Dhoruriat because without elements under Al-Hajiyyat, the society does not fall into disruption or damage as inferred earlier in Al-Dhoruriat. Without Al-Hajiyyat, the outcome is that people suffer and face difficulties to duly perform the commands from Allah. As Imam Syatibi describes, the non-existence of Al-Hajiyyat will render some kind of hardship and burden to the but will not bring severe impact to the five elements.

3. At-Tahsiniyyat (the embellishments) in Arabic is termed as التحسينيات, which according to Imam Ghazali are those that does not reach the level of dhoruriat and hajiyyat, but is an improvement to a development of a state or condition (Al-Ghazali, 1995). Tahsiniyyat elements are things that lead to the improvement and perfection of life, which without it will not cause a burden or difficulty as in the other two categories.

\section{Islam Celebrates Ethnic Diversity}

The religion of Islam highly honours the values of harmony and justice. Allah SWT says :

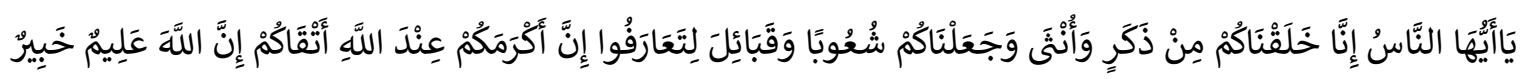

Meaning: O mankind! We created You from a single (pair) of a male and a female, And made you into Nations and tribes, that Ye may know each other (Not that ye may despise each other)/ Verily The most honoured of you in the sight of God is (he who is) the most Righteous of you. And God has full knowledge And is well acquainted (with all things) (Al-Hujaraat : 13) This verse proves that Islam accepts cultural, national, and religious diversity in life. Humans are created by Allah in various shapes, groups, and cultures, and acceptance and respect of these diversity and differences as part of the natural order.

Differences in culture, religion, and nationalities should not cause enmity and division. However, these differences reflect Allah's Power to those who ponder and think. Allah says :

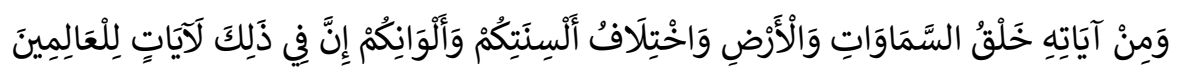

Meaning: And among His Signs is the creation of the heavens and the earth, and the variations in your languages and your colours: verily in that are Signs for those who know (Ar-Rum :22).

In observing the historical development of Islamic kingdoms,. we can measure to an extent the role Islam played in advancing the process of development of universal and comprehensive basic human rights, during a period when the West were still struggling with defining their basic rights. This was seen in the peaceful lives of non-Muslim in Islamic countries, whose rights were guaranteed and safeguarded in the Qur'an and Sunnah as well as constitutionally, especially in Malaysia.

Islam does not use religious differences as an influential factor in nation-building, and non-Muslims are celebrated and placed in honourable positions in line with their status as 
fellow human beings. This was reflected in history through the ratification of the Constitution of Medina, which contained the basis of universal human rights. The need to harmonise the needs of the population of Medina, with religious and ethnic diversity, was the first important task faced and solved by the Holy Prophet Rasulullah. The Prophet Muhammad PBUH came up with the Medina Constitution in $622 \mathrm{CE}$, or the first Year of Hijrah, and it was the first written constitution in the world. The contents of the Constitution are the 47 clauses:

- 23 clauses discuss the relationship between the Muslim communities of the Ansar and the Muhajirin.

- $\quad$ The remaining 24 clauses deal with the relationship between Muslims and nonMuslims, e.g. the Jewish community.

The formation of this constitution underwent an organised process, with Rasulullah taking almost two years to complete the full text of the constitution. The clauses regarding Muslim-Jewish relations were completed before the Battle of Badr al-Kubra, while the remaining clauses on intra-Muslims relations were completed after the battle. The provisions on basic rights must be implemented to ensure smooth administration. The constitution contains 47 clauses, which in principle describes the main policies in matters of statecraft, including citizenship, commitment to negotiation, commitment to mutual defence, commitment to finance, guarantee of freedom of worship, and guarantee of peace.

The early policies set by Rasulullah in the Medina Constitution were not static, but went through updates and improvements towards a more universal and comprehensive basic rights. This process occurs through proper understanding of the texts of the Qur-an and the Sunnah, interpreted by the sahabat and the later generations in showing the principles of statehood according to Islam.

\section{Social Justice in Malaysian Racial Society}

Malaysia is a unique country with a multi-confessional population. According to the Department of Statistics, in 2010, of the 28 million people here, 61.32 per cent are Muslims, 19.84 per cent are Buddhists, 9.24 per cent are Christians, 6.27 per cent are Hindus, and 1.26 per cent follow Chinese traditional religions. The rest follow other faiths.

In the context of Malaysian society, the Federal Constitution is the core in the concept of justice, unifying the diversity of ethnic and religious groups. The long history of inter-ethnic and inter-religious mingling serve as the framework in the formation of this constitution. Even with the notable presence of both majority and minority groups, the constitution does not limit the just demands of all races. The social contract provides a balance to the concept of social justice in Malaysia. Provisions to traditional elements, balanced with the requirements of citizenship, should be fully understood as they form the basis of social stability in this country (Abas, 1985; Muslim \& Samian, 2012). These traditional elements refer to the four articles in the Constitution of Malaysia, which are i) the Malay Rulers, ii) Islam, iii) the Malay language, and iv) the special position of the Bumiputera. Although these traditional elements mainly concern the Malays, it is also balanced out by the realistic needs of other ethnic groups.

The Malaysian Constitution recognises the sovereignty of the Malay Rulers, as this institution is a part of the national social system, a symbol of history, and a recognition of the role of the sultans who once wielded full authority in this land. This historical symbol is not only recognised in Malaysia, but also in other countries that look to historical symbols to 
strengthen national spirit. Symbols and identities often become factors in strife and conflict in some countries. The presence of the royal institution serve to prevent this crisis of identity (Bari, 2008). In fact, the position of the Malay Rulers are not unjust, as they powers are limited within the ambit of democratic rule, framed as 'Constitutional Monarchy.' As a democratic country, aside from the judiciary and legislative, the executive body has a multi-ethnic makeup, and serve as the executor of national agenda.

Article 3(1) of the Constitution states that Islam is the religion for the Federation, but also allows other religions to be practised in peace and harmony in any part of the Federation. There is no injustice towards other religions, as this provision reflects the freedom of worship enjoyed by all ethnic groups. Islam, and even the Constitution, does not compel adherents of other faiths to convert to Islam. The syariah legal system is in place to handle matters pertaining to marriage, divorce, family, and inheritance, and its powers are quite limited and only applies to Muslims. Therefore, the rights and demands of other religions are celebrated in their capacity as legal citizens. This balance of rights are important to bring harmony to the multi-ethnic and multi-religious relationships in this country.

Article 152 of the Constitution guarantees the Malay language as the National language, but everyone is free to teach, learn or use any other languages, except for official purposes. Furthermore, the Federal and State Governments are free to preserve or sustain the use and study of the language of any other community. This provision also reflects justice enjoyed by all groups, and to preserve the existing languages in Malaysia. The Malaysian education system allows the setting up of national-type schools, which uses their mother tongue as the language of instruction, even though Malay is the national language of Malaysia. Therefore, language as the identity of a people is preserved in the Constitution, even with the provision of Malay as the national language in order to unite the multi-ethnic peoples within a framework of national identity.

Article 153 stipulates that the Yang di-Pertuan Agong, acting on the advice of the Cabinet, has the responsibility for safeguarding the special position of Malays and the indigenous peoples of Sabah and Sarawak, as well as the legitimate interests of all other communities. Bumiputera special rights are guaranteed in the Constitution as recognition of them as sons of the soil. It also plays a role in determining social justice, especially in matter of national economic equity. From an economic perspective, justice often refers to adequate financial support for people from low incomes, closing the gap between high and low income groups, and equitable economic opportunities. As a result of the long era of colonialism, the Malays were kept out of the main national economic sectors. The climax of this situation was the 13 May 1969 racial riots, caused by resentment from the blatant economic inequality between ethnic groups (Comber, 2011; Ibrahim, 2011). In the wake of the racial riots, the government implemented the New Economic Policy (NEP) to eradicate poverty and narrow the economic gap between groups between 1970 and 1990. The NEP has often been accused as discriminatory, since its policies to restructure the economy focuses on the Malays. This stigma happens due to strong ethnocentric views, without taking into account the need for a more equitable social system to further strengthen national continuity. The NEP also did not achieve one hundred per cent of its intended objectives. However, the economic gap between ethnic groups have improved and is not as obvious as before. Today, the economy is more focused towards economic stability and sustainability, independent from a focus on ethnic economic development.

The struggle for social justice within the framework of $21^{\text {st }}$ century Malaysia is more challenging and global in nature. Issues of gender inequality in a more open context, as well 
as the unfair treatment of minorities such as the LGBT community are discussed in a more open manner. These groups fight for their rights within the framework of Western-based human rights. The Principles of the Rukun Negara (Pillars of Principles), based on Belief in God, and Courtesy and Morality, which served as the basis of Malaysian values should be strengthened. Malaysia highly values the role of religion as the basis of human morality in line with the nature of creation. Based on the principles of the Rukun Negara. Acts and behaviours not in line with the multi-ethnic societal mores could not be accepted.

The view of social justice changes with the level of resolution, depending on whether we are conceptualising justice at the level of individuals or groups and communities (Watts \& Hodgson, 2019). Therefore, social justice issues in multi-ethnic Malaysia needs to be discussed even further within the framework of the provisions in the Federal Constitution, as well as other just and equal national policies. The media plays an important role in disseminating issues of injustice and contain the spread of negative agenda to the people.

\section{Social Media as a Tool for Social Justice}

The communication and media technologies have widened the gap between the urban and rural communities. Furthermore, the latest developments, known as social media, has brought the proliferation to the new media technology. In promoting social justice among the ethnic groups in Malaysia, social media can be the platform to serve public interest, specifically to increase their social interaction through conversations, chatting, networking and so on (Schejter \& Tiros, 2015).

In Malaysia, the issue of social justice has been debated in many platforms and from different perspectives. As have been discussed earlier, issues related to social justice in Malaysia is very much related to poverty, disadvantages, injustice, oppression, stigma, discrimination, education, health, economy et cetera. Social justice is based on equality of rights for all people and the possibility for all human beings, without discrimination, to benefit from economic and social progress everywhere (Dudley, 2016). Therefore, in order to provide more understanding of the definitions and concepts of social justice, the media has the power to disseminate information, evidence, and statistics to the public, and most importantly, it can serve as a vehicle to increase understanding among multi-racial in Malaysia. The unique characteristics and the capabilities of the media means it has a great potential to enhance its function among users to interact at any time and at any place, as a medium to contribute peace and harmony among the people, and eventually has a more positive impact on society (Schejter \& Tiros, 2015).

According to the report by Modern Diplomacy (2019), the internet has actually provided us the platforms where society can share their thoughts, ideas, voice out for their rights, or against injustice. For example, the social media has been used aggressively during the political campaign through hashtags, videos and photos. Many of the politicians, supporters and the public used social media such as Facebook and Twitter as platforms to spread their ideas to gain support and trust. This situation allows society to argue as well.

According to the World Summit for Social Development (1995) society can be described as for all in which every individual, each with rights and responsibilities, has an active role to play (in Yatimah, 2017). Meanwhile, UNESCO 2012 stated that a society for everyone should be built on fundamental values of fairness, equality, social justice, human rights and freedom as well as on the principle of tolerance and diversity. Based on these two definitions, it can be understood that each society, regardless of gender, ethnicity, socioeconomic levels, and geographical locations, have the right to live peacefully regardless of 
their background, in order to achieve the full potential in life. But, the dilemma is, can this situation happen?

The discussion leads to the topic about the practising of social justice in Malaysia. The notion of social justice is every person in the world can enjoy equal rights. However, some segments of the society has misused the interpretation of social justice, and this eventually leads to chaos, riots, depression, et cetera. Thus, the media can be a platform to disseminate proper understanding, knowledge, campaign and so on. For example, Glick (2015) said that many advocates and activists also using social media to spread and shared their perspectives on certain issues. The social media such as Facebook and Twitter have made many voices and causes heard. Other than that, Khandelwal (2019) suggested that creating society through a social media shows that we are actually take seriously on the human rights issue. Therefore, the social media should be used to organize events for example marches, protests, meetings and so on, to let other people know that the NGO or government are doing something for the benefit of the society in order to spread understanding and giving them a right platform to vocal out their rights and voices.

The plethora of online platforms available to the citizens of the world can be used in many different reasons especially creating a more positive environment. Through social media, we can see actually that many things happened and updated in the social media such as news, rumors, cyber-bullying, cyber-crime, cheating and so on. However, the researchers do believe that social media has its own positive impacts and can be used wisely apart from all the negative things. Apart from that, social media also can be an online place for people to fight their rights by spreading messages and stories to be shared for the people all over the world.

\section{Conclusion}

Malaysia's position as a Muslim country, able to harmonise relations between its multi-ethnic and multi-confessional peoples, is a model and reference to other countries. Malaysia is a good answer to the negative stigma held towards Islam as a harsh and backwards religion. The Maqasid Syariah framework, which prioritises protection of religion, the self, the intellect, progeny, and wealth, is in line with the Federal Constitution, by taking into account concepts of justice to all ethnic groups.

Therefore, social interaction between Muslims and non-Muslims in Malaysia instils suitable principles of interaction in bringing harmony to social relations between the groups. Basically, a number of studies were done on the core and principles required to ensure this interaction does not veer away from the demands of the syara'. Yusof (2006) and Musa (2011) have written works on the preservation of the principle of freedom of worship by nonMuslims loyal to Muslim leaders.

The principle of interaction via interfaith dialogue should also be encouraged, with Islam emphasising its followers to take a more inclusive approach to religious diversity, without affecting the basic framework and understanding on tauhid. Islam also welcomes peaceful discussion, rational, not emotional and tense. Allah says :

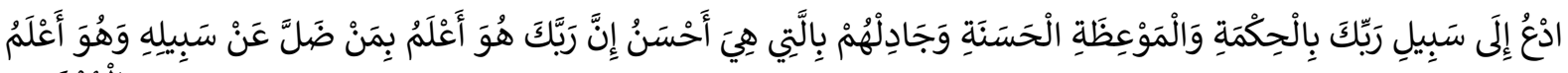
بِإِمْهُتَدِينَ 
Meaning: Invite (all) to the Way of Thy Lord with wisdom and beautiful preaching; and argue with them in ways that are best and most gracious: For thy lord knoweth best, who have strayed from His path, and who receive guidance (Surah An-Nahl:125)

Therefore, the direction of the struggle for social justice within a multi-ethnic framework in Malaysia must be based on internal values and sources. The Maqasid Syariah, which stresses on the maslahah aspect, should be a source of guidance that emphasises moral values in line with and beneficial to the multi-confessional peoples of Malaysia. Western enculturation, including the ever-growing field of knowledge, should be in line with the context of national identity. Social justice, untethered to national identity, can only lead to wider injustice, as each country have their own unique social fabric.

Racial unity within the framework of Maqasid Syariah should be actively promoted by local social media, in order for the main agenda to restore sentiments of justice, balance, and equality can strengthen the national spirit of each citizen, within the Malaysian socio-cultural aspect. Determining the element of loyalty to the country, instilled in the heart of every Malaysian, is seen as an important basis of maintaining harmony and unity among the people of this nation.

This research contributes theoretical knowledge on the significance of Maqasid Syariah in discussing the issues of social justice and how it was relevant to the contextual situation of the racial society, especially for Malaysians. This paper also emphasizes the cross-discipline research in adapting the media paradigm for promoting social justice through the Maqasid Syariah framework.

\section{References}

Al-Quran.

Al-Ghazali. (1995). al-Mustasfa. Beirut: Darul Kutub.

Abas, M. S. (1985). Unsur-unsur Tradisi dalam Perlembagaan Malaysia. Kuala Lumpur: Dewan Bahasa dan Pustaka.

Avineri, N., Graham, L. R., Johnson, E. J., Riner, R. C., \& Rosa, J. (2019). Reimagining Language and Social Justice. In N. Avineri, L. R. Graham, E. J. Johnson, R. C. Riner, \& J. Rosa (Eds.). Language and Social Justice in Practice (pp. 1-16). New York and London: Routledge. https://doi.org/10.1080/10350330.2019.1623499

Bari, A. A. (2008). Perlembagaan Malaysia: Teori \& Praktis. Shah Alam: Arah Publications.

Capenheart, Loretta \& Milovanovic, D (2007). Social Justice: Theories, Issues, and Movements. New Brunswick, NJ: Rutgers University Press.

Comber, L. (2011). Peristiwa 13 Mei: Sejarah Perhubungan Melayu-Cina. Translated by Omardin Haji Ashaari. Selangor: IBS Buku Sdn Bhd.

Dudley, R. (2016). Right To Social Justice. in The Star. Feb, 20, 2016. Retrieved at https://www.thestar.com.my/opinion/letters/2016/02/20/right-to-social-justice

Glick, H. (2015). Putting Social Media To Work For Social Justice. Retrieved at https://www.globalcitizen.org/en/content/putting-social-media-to-work-for-socialjustice/

Green, D. P., Glaser, J., \& Rich, A. (1998). From lynching to gay bashing: The elusive connection between economic conditions and hate crimes. Journal of Personality and Social Psychology, 75(1), 82-92.

Henderson, K. I., Martín-Corredor, L. \& Caffrey, G. (2019). Issues of Equity in Dual Language Bilingual Education. In N. Avineri, L. R. Graham, E. J. Johnson, R. C. Riner, \& J. Rosa (Eds.), 
Language and Social Justice in Practice (pp. 63-71). New York and London: Routledge. https://doi.org/10.1080/10350330.2019.1623499

Ibn Khaldun. (1967). The Muqaddimah: An Introduction to History. Translated by Franz Rosenthal. Princeton, NJ: Princeton University Press.

Ibrahim, A. R. (2011). 13 Mei 1969. Kuala Lumpur: Dewan Bahasa dan Pustaka.

Khandelwal, D. (2019). The Marriage of Social Media and Social Justice. Retrieved at (https://moderndiplomacy.eu/2019/01/18/the-marriage-of-social-media-and-socialjustice/).

Modern Diplomacy. (2019). Retrieved from https://moderndiplomacy.eu/2019/01/18/themarriage-of-social-media-and-social-justice/.

Musa, Z. M. (2011). Hak-hak mengamalkan Ajaran Agama Masyarakat Non-Muslim dalam sebuah Negara Islam. In Abdul Karim Ali \& Rumaizi Ahmad (Eds.), Fiqh masyarakat NonMuslim di Malaysia (pp. 70-73). Shah Alam : Imtiyaz Multimedia \& Publication.

Muslim, N., \& Samian, A. L. (2012). Tahap Penerimaan Pelajar terhadap Peruntukan Bahasa Melayu dalam Perlembagaan Persekutuan. International Journal of the Malay World and Civilisation (Iman), 30(1), 3-27.

Reagan, T. (2019). Linguistic Legitimacy and Social Justice. Switzerland: Palgrave Macmillan. https://doi.org/10.1007/978-3-030-10967-7

Schejter, A., \& Tiros, N. (2015). Seek The Meek, Seek The Just. Telecommunications Policy, 39(2015) 796-803

Watts, L., \& Hodgson, D. (2019). Social Justice Theory and Practice for Social Work: Critical and Philosophical Perspectives. Springer: Singapore. https://doi.org/10.1007/978-981-133621-8

Yatimah, S. (2017). Women Empowerment - The Malaysian Contexts. Report from Ministry of Women, Family \& Community Development Malaysia.

Yusof, N. M. (2006). Toleransi Beragama dan Kesesuain Hukuman Murtad di Malaysia. Proceeding of Seminar Islam dan Hubungan antara Agama di Malaysia, Universiti Malaya, Januari 2006), 15-20. 